\section{REIIAAR GRONHAUG}

Scale as a Variable in Analysis: Fields in Social Organization in Herat, Northwest Afghanistan

1. Introduction: The scale of what? 1.1 What hinds of sub-systems have scale?

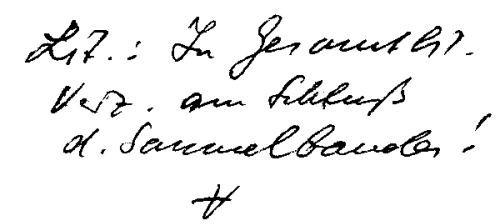

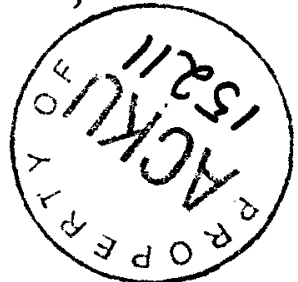

Characterizations of whole sucieties as being 'large-scale' or 'smallinale" are in miny cases lome and vinue. It is hopeless to try to devide whether scale really is an important characteristic of social ingatization, unless we can first establish a sufficiently precise anchod for determining empirically the scale of the phenomena in que tion. Such a method is a prerequisite for any discussion of the structural corrollaries of the scale of a society.

What kinds of unit:s should we use for validly characterizing a 'society' in terms of scale? It is difficult to start with the whole of a 'oriety' as the initial unit, because there is so much we must learn before we can empirically describe it. A case like Luxembourg can be described in emic terms as a state unit emcompassing a variety of smaller units. For many purposes - political, cultural, economic Lux'mbourg's inhabitants are also part of larger surrounding systems that affect everyday life in Luxembourg. Some of these contexts are recognized in emic rules, such as the formal organization of the El:C; others are not so cle:arly codified, such as the wider mirnational market, power, and ecologic flow patterns affecting liic within Luxcmbourg. How should we then circumscribe the l.11 xembourgians' 'society'?

In any case we cannot immediately apply an emic view of socicty, e.g. at state or tribal unit, as a basis for defining in etic toms the relevant societal whole. The nature of that whole and its size cannot easily be known at the beginning of investigation. We 'ath only hope to understand it through a process of discovery. It is impossible to know beforehand which level of scale is certain to display the most relevant determinants of overall social lif: in an wherved population.

II'c can start wbscrvation at 'any convenient locality' (Radcliffelirwn 1968: 193j. But, we should be prepared to expand or conIt.. the seate of the area and population under study if we can dureloy more clatly understand the initially observed regularities.
We can imagine various ways of analytically dividing a larger societal whole and circumscribing the sub-units. The que'stion is how, theoretically and methodologically, to derive units both valid and structurally critical. Taking up this problem, I will start by clarifying the lerm "scale".

\subsection{Defining scale}

I will use 'scale' to designate size, the 'scale' of an organizat ional unit being the number of people involved and the unit's cxtension in social space. An empirical system can be described in terins of scale, granted we can delineate its boundaries in social space and time, and can identify the social interlinking of involved personnel. I will attribute scalle to social units which in any case enconinsass a set of individuals interlinked by urganization and communication.

Scale, in this sense of size, includes two dissimilar dimensions: the number of personnel and extension in social space. A corollary of these is the density of people in space. Sometimes we must distinguish among these dimensions; we can further avoid obscurities in our discussion by referring, when necessary, to 'numbers', 'space', or 'density'.

'Structural complexity', though related to these dimensions, is distinct from them. By 'complexity' I am referring to the numbers of roles and the combinations and permutations of roles. Societies differ in the ways roles are distinguished and combined; they differ regarding numbers of role-codes and codes' productivily in generating varieties of social person-types.

A small socictal unit may be structurally highly complex (modern Luxembourg), and one of large scale structurally simpler (the Mongol Lin] ire). The Mongol Empire displayed a considerable number of kinship, ethnic, military rank, economic, and other roles; but at the same time it produced only a limited range of sucial person types, cach type tending to display a standard combination of a certain number of roles. In contrast, Luxembourg society is more complex in the sense that it rapidly produces new role forms to be combined in rather non-repetitive types of social persons. A greater variation of role pernutations thus characterizes the constitution of social persons in L.uxembourg.

We can use the number of roles and watys of combining roles into social persons as variable's in comparative exercise's (cf. Barth 1972), and I make this point the basis for my notion of 'struitural complexity'. Complexity then refers to the number of ruis and the number and variety of social person-types. Further, complexity is an aspect of social and cultural structures in gencral, such as dis- 
inction of levels in social hierarchies and the degree of differentiation in communicative codes - but much of this relates to role patterns which I will focus upon in my discussion.

It i) a matter of terminological convenience whether or not we inc'ule complexity as another specific dimension under one broad label 'scale'. However, since we want to compare the logical and empirical relations between size and complexity in social systems, we must question ideas about levels of complexity as corollaries of levels of scale. Our problem is the relations between size and complexity. ${ }^{2}$

Here it is convenient to distinguish size from complexity, reserving the term 'scale' for the former. In the following, 'scale' will mean extension in social space and number of personnel in a social system, and 'complexity' will pertain to the degree of role differentiation and the varieties of role permutations in the system. Scale and complexity are two separable aspects of society, and I want to study empirically the way they relate to each other.

\section{The multiple levels of scale in one society.}

My point of departure is Redfield's questions:

$\therefore$. . Considering a peasant community as a system of social relations, as social structure, how shall we describe its relations with the world outside that community? . . .

and

.. Because no one village is really independent, but is a part of a much larger and more complicated system, our interest is drawn tuwards the description of the more complicated system. . . And how shall one study so large and complex an entity? . . (Redfield 1967a: 128, 1967b: 24).

In this paper I present a method for the observation and analytic description of social life within its macro-context, a procedure developed during studies in the regions of Antalya, Southern Turkey, and Herat, Northwest Afghanistan.. ${ }^{3}$ In this analysis of sorial life in Herat I gradually clarify my methodological steps while moving from one empirical aspect to another, from a single to a more composite picture of the society.

Initially the description focusses on the little community, since this correpponds to the course of my fieldwurk observations. This however, does not imply viewing the local rural community in Herat as especially significant in comparison with other types of organizational units there. In fact, the typical rural locality in Herat is an extraordinary weak form of organization with a limited potential for mobilization.

Local communities do not appear to have the same structural importance in all societies, or at all times during the history of one society. In the discussion below I contrast the structural importance of the local community with that of other organizational entities at different levels of scale within the larger societal whole.

In Redfield's remark it is implied that his peasants live within units of small scale, 'the little community', and at the same time within more inclusive 'systems' of much larger scale. But what kind of units and systems, and how large?

In addition to the units of village-district-province and the like, villagers in Herat recognize and live within a series of other organizational entities. Many of these are of much larger scale than the little community, and they differ in scale among themselves so that they do not all belong to the same equally 'macro' level. They also differ in organizational form and content, and the extensions and directions of the social relation patterns vary.

I will describe empirically some specific sub-populations that are dispersed in social space and interlinked in social organization. In each case I identify a social 'proper dynamics' that generate the organizational and statistical pattern in question. The idea is to look for the social dynamics that create direct and indirect links and repercussions within a population so that it emerges as an aggregate entity with attributes of scale and complexity. I will be interested in an organizational entity to the extent that it displays some specific structural implications which are irreducible to the pattern of other entities. 'Structural implications' means here effects upon the individual social person, as well as upon the societal system as a whole.

The empirical systems will be shown to contain emic codes, rules, and categories which Herati people know and apply, but it is in etic terms that I will define and select the entities. I treat them as super-individual systems conditioning the lives of individuals, whatever the subjective hopes and strategies of these individuals may be.

These empirical systems vary, from well-defined corporate groups, to mere aggregates of interrelated actors who themselves may be unaware of any social interlinking among theniselves. The units differ in form and scale, but they display in common certain basic features allowing for an uniform terminology. I will call these units or systems of social interconnexions 'social fields'. 
In the study of large-scale entities, anthropologists lawe special problems in data collection. Both in Antalya and in Herat I first initially spent a few weeks surveying the overall region, and then a considerable part of the total fieldwork period in one selected locality. From there I followed the villagers out into the region as they engaged themselves in specific tasks vis-à-vis different role- and network-partners dispersed over the area. At the conclusion of my stay I attempted a short re-survey of the region. Previous to the fieldwork I had read some anthropology, history, geography, statistics, and other writings on Afghanistan. When mapping largescale fields, anthropologists can use secondary statistical and other material; but most importantly we have to adapt participant observation, and specific techniques for primary data collection, to fit the study of large-scale entities. We return to this question in the various following sections, particularly when discussing regional organization (3.5)

In the remainder of this paper I describe a series of social fields in Herat and discuss the procedural rules pertaining to their discoverv. The aim is to find their organizational patterns, levels of scale, and interrelations with each other. Specifically, I will try to describe and evaluate the order among social fields, in the sense of their relative weight or dominance within the processes of maintenance and change of general social life in Herat.

I take 'society' to be a whole that contains the total set of social prerequisites and determinants for individual lives, the social production and destruction of human beings. Initially, the anthropologist cannot know how to circumscribe the relevant 'society', to ineasure it, or to count its members. In order to describe society in Herat I must first define relevant kinds of analytic units and discover how to study their interrelations.

Let us begin with a discussion of the local field, and then relate it to other more inclusive systems in Herat.

\section{Fields at various levels of scale in Herat.}

\subsection{Locality}

3.1.1 A short description

A striking feature of the average village in the Herat valley is the high and rapid turn-over in locality membership. The little community in Herat is only to a very limited extent 'a cradle-to-thegrave arrangement', as Redfield put it. In a neighbourhood of abour twenty households, one third may have lived there two srcuerations or more, another third a decade or two, and the rest only a few years or less. The typical village is like a wayside station: households come there, stay for a period, then leave. Villagers live in tight complexes or blocks of houses built of dried mud, but next-door neighbours have in many cases never met before moving in to the same village.

Population density is high in the irrigated areas of Herat. A village of about twenty households may use an acreage of not more than 400-500 decares, which amounts to a population density of 200-300 per square kilometer. Average density in the canal areas is much higher, some places approaching 1000 individuals per square kilometer. A small neighbourhood within this compactly populated canal area will be my empirical focal point throughout the following discussion.

Most villagers are sharecroppers, tilling the land of a resident or absentee landowner. The latter typically resides in the town of Herat. Some sharecroppers also own a little land, and a few villagers are freeholders working exclusively their own land. Within the normal pattern of household development, members of freeholder families will themselves become sharecroppers and some sharecroppers will rise to become freeholders. In general, the statuses of worker, sharecropper, and freeholder constitute stages, over a generation or two, in the cyclical development of agriculturalist families.

Agricultural workers and sharecroppers without land or oxen are the people who most often shift residence. Sharecroppers possessing one or two oxen tend to reside more permanently at one place; and if they also own a little local land, they may be among the old-timers of the village.

The lack of residential permanence relates directly to landownersharecropper relations. The landowner may choose not to renew the annual contract if dissatisfied with the work performance of the sharecropper hous ehold. The latter must then leave the agricultural land and the dwelling included in the contract; since sharecroppers may have no other tie to the locality in question, they will be forced to move away. The pattern has many brutal effects; during the process, many sharecroppers and workers become beggars, some collecting alms in their old neighbourhood, others roaming widely and never returning to the neighbourhood.

The households of a village display economic situations ranging from relative security to veritable despair. Freeholders and sharecroppers with a little land and other productive means may enjoy a fairly good standard of living and an adequate diet. At the other extreme are unpropertied poor people, many of whom display a terrible syndrome of debt, hunger, and tuberculosis. 
Even very small neighbourhoods are ethnically heterogeneous. Most people speak Dari, the Alghan version of Persian, but one, two or more other languages are also found. Many persons are bilingual. People reckon themselves as belonging to one of a number of 'tribal' or ethnic categories without any implications of corporate organization or territorial belonging. A small village may represent the categories of 'Tadjik', 'Afghan', 'Timuri', 'Taimenni', 'Moghol', 'Turkmen', 'Jat', and others, plus a multitude of sub-categories. It is common to find five or six different main categories within a neighbourhood of say twenty households.

The overwhelming majority of villagers belong to the Hanefi religious rite. Different Sufi sects are also present, and the introduction of one of them into a village may lead to some division, since many mullahs dislike such sects. Most villagers go to the mosque for prayers at least in the morning and at sunset. The mullahs are also geographically mobile; they stay only for a short period with a specific local congregation before moving to another place.

The political scene in the villages of the Herat Valley displays a relative absence of large factions and alliances to be mobilized in contests for community leadership and in conflicts over land, women, and other matters of honour. This is not surprising if we consider the Herati villagers' general situation. In land conflicts, sharecroppers have no reaion to tight for their landlords' soil. The sharecropper is mobile, shifting his attachment to different villages and different plots, and the bond between him and his landlord rarely develops much beyond specific contractual rights and obligations.

Among Herati villagers, conflicts of honour are rare, and when they do occur, they seldom lead to violent feuds. A villager will have difficulties mobilizing local support for such issues. Due to the near-universal mobility, his relatives are not present as a solid block in one community but are scattered around as a di spersed network in the region. In conflicts of this kind, it is more common for one of the parties, typically the insulted one, to move away from the trouble, seeking a sharecropping job and residence in a sufficiently distant village.

If a big landlord lives in the village or has appointed an overseer to manage affairs for him, a kind of leadership is present in the villiage; but this pertains only to a limited set of economic issues. Left to themselves, village residents do not display any strong conmunity initiative on the basis of their own neighbourhood organization. It is even difficult for them to mobilize for simple whinical tasks with obvious collective benefits, such as repairing irrigation canals. In matters of this kind, state authorities at the district level frequently intervene, ordering pcople to act (see 3.2.1.). ${ }^{6}$

In the light of the geographical mobility and the ethnic heterogeneity of Herati villagers, it is striking how well people within the individual village do manage to coordinate their agricultural work. Irrigation procedures, canal maintenance, harvesting, and crop distribution require repetitive agreements, meetings, and intricate forms of cooperation among households. In the hectic work routine there is no place for differences of 'tribe' or religious interests, or for insulting other men's honour. The sharecropper is a veritable slave of his work; he labours for his family's bread and landlord's rent, and submits to the demands for work cooperation.

Summing up: (1) The average village in Herat is characterized by a strikingly high turn-over; and the overall agriculturalist population has a low degree of residential permanence. (2) Within the individual locality very few parts of community arrangements are based upon kinship. Any villager will find only a few of his relatives. in his village of residence; the rest are scattered around the region.

(3) Individuals and households are recruited to a village by establishing contractual relations with local landlords, by purchasing land of their own, or, in a very few cases, by establishing themselves as rural craftsmen or shopkeepers.

(4) Villagers families tend to stay at one place as long as they are able to maintain economic viability and fulfil sharecropper obligations. Maintaining a household presumes an equilibrium among domestic consumption needs, labour force, resource control, and income. The effects of domestic development on personnel composition will determine in individual cases the ratio of consumers to workers in a household. The unit's access to land and employment depends upon local ecologic conditions and competition in the market for sharecroppers' labour. Greater competition means allotment of smaller plots to individual households, increasing rent and decreasing renumeration in kind to sharecroppers. Thereby the viability of individual houscholds is precariously endangered.

(5) Very many households experience budgetary imbalance. The worker(s) of the family fall ill, or crops are insufficient, and this leads to borrowing and falling into debt - oxen are sold to cover immediate consumption needs, and so on. If the household's economic capacity is thereby reduced, the landlord may be unwilling to renew his contract with the sharecropper. The latter must then leave the locality.

On the other hand, households can also increase their assets: at certain stages in the domestic development pattern there is a 
favourable ratio of workers to consumers, whereby the unit may be able to accumulate a small surplus to buy oxen and land. The household will try to use its assets optimally; and if this cannot be achieved in its place of residence, the hous ehold may move to a village with more favourable conditions.

Combining the above points, we observe that the locality is (6) normally not arranged as a set of solid corporate groups or factions, and has (7) an extremely weak potential for staging corporate action and for defining and promoting common community goals.

(8) Some important determinants behind the above features of locality forms are found in landowner-sharecropper relations, irrigation technology, and Hanefi Islam which organizes the neighbourhood as a congregation; in many cases the mosque is the only really collective forum in the locality. It is characteristic, however, that religious life has extremely limited organizational consequences for the local population as a community. Moreover, a.l three determinants - property, irrigation and religion - are parts of social fields of larger scale than the locality itself.

\subsubsection{Analytic procedures}

Although locality can be seen as a social field in itself, we should not include everything observed from local scenes in the analytic entity treated as 'locality'. In the total picture, locality is just one field among others, and we need a multi-field picture to evaluate how significant locality is in comparison with other fields, i.e. how strongly it determines the formation of the societal whole and the social person. (cf. Grønhaug 1971, 197lb, and: in press).

Locality must be analyzed so as to facilitate discovery of units at scile levels larger and smaller than itself. On one hand, events in large-scale fields affect local level processes: regional personne! circulation, macro-ecological and economic flow-patterns, and so forth. On the other hand, there are units smaller than locality, such as the domestic field, and ultimately the levels of person and sub-person: role-repertoires and specific roles.

Wie can identify locality as a social field in Herat by looking at (1) the relative durability of interaction among (2) a limited number of persons living (3) close to each other within limited space. Locality can in this sense be seen as (4) a specific forum, or a set of fora, within which the members act in the presence of each other as social persons and in specifically intense ways.

Members of a locality handle (5) a series of tasks and issues vis-àvis each other: co-residents are also co-workers, and in addition the $y$ relate to one another in other tasks and role-sets. Integration processes thereby create multiplexity in local relations.
The actual degree of (6) emerging multiplexity is the cumulative effect of specific integration processes, which in turn depend upon the tasks and issues in local interaction. Thus localities within one society, and also cross-culturally, can be shown to differ with respect to multiplexity. As a main empirical feature from the above, social relations within Herati villages display a comparatively low level of multiplexity. For this reason I have preferred to label the units 'localities', rather than 'local communities'.

Herati villagers stay only for limited periods in one locality. But whether they stay in the same small place for ten or five years, or only for one, (7) much information about their previous behaviour is nonetheless carried over from situation to situation. The locality thereby emerges as a social milieu where multiplexity develops in social relations and information is created and stored. This contrasts with many other fields in Herat - e.g. regional organization, where inter-personal relations are much more single-stranded, as will be shown later.

In any minimally stable milieu there are (8) events which participants regard as critical for their own interrelations. Such events encompass issues of work, power, kinship, ritual, and so forth, but members of the locality experience them as one continuous whole which they associate and label with their village or neighbourhood name. These events contain the potentialities of (9) tension and fission; there is a continuous need for negotiation and the establishment of agreement.

(10) The points above show the small scale of effective locality in Herat - one to a few hundred people; as well as its proper dynamics of emerging multiplexity, fusion, and fission in relations among locally residing actors. Thereby, we have isolated locality as a field of social interconnexions with characteristic organizational dynamics and a specific scale - size, extension, and density, and also a typical pattern of development over time. Locality corresponds to only one of the many aspects of the lives of locally residing actors.

Localities in Herat vary in scale, multiplexity of internal relations, cohesion, and in the potential for communal initiative and mobilization. Within limits, they differ as determinants in the formation of the social person. The above picture characterizes the typical mode of local organization found among agriculturalist villagers in Herat.

Locality studies are then especially concerned with what happens in intri-local relations when a set of individuals, within the context of larger and smaller fields affecting local processes, reside together for some time in alimited area. 


\subsubsection{What is not locality in Herat}

Should we not specifically discuss the ecology or economy of the village, the little community as a system of kinship or stratification, the religicus aspect of village life, and so forth? Village life obviously displays features which can be understood only with reference to such categories. Indeed, I have already considered these as elements within the locality system. But in this way we do not obtain a proper understanding of these categories.

In the case of Middle Eastern and Central Asian societies, as in so inany others, it is more fruitful to treat systems such as economy, stratification, kinship, religion as social fields of their own, whose organization and scale are normally not concomitant with locality. When we pursue in Herat the empirical relations that correspond to these various fields, we find networks and patterns of organization that extend far beyond the single locality.

It would be perfectly valid to treat the little locality as an ecosystem, as an ecologic field, but the relevance of this for the present task is questionable. The nature and impact of ecologic forces will be seen much more clearly if, beginning in one locality, we pursue the social relations that are in fact activated in the use of locally relevant energy resources. We will then find network and ecologic arrangements that encompass great numbers of localities.

We can similarly speak of villagers' religious life. Following the above procedure we can point to religious events in the neighbourhood that are connected with events of work, kinship, and local politics - all of which make up community life at large. The same actors' relations in the larger set of religious fora situated outside their own village, however, are a different thing. Although applied locally, Hanefi codes are not produced there; they emanate from within a far more extensive field of communication. Like ordinary people, religious specialists in Herat are mobile. Participation in Mluslim ritual does not depend upon being nember of the locality. The organization of religion, like that of kinship and ecology in Herat, displays its own network forms with their own levels of scale which cannot be understood solely as aspects of the little community.

These brief remarks on kinship indicate that the villages are not kinship-based groups, and that Herati kinship cannot be seen as a prinary aspect of locality life. The individual family-based househol! utilizes its relations with kinsmen as sources of help and support, but on the interaction level, the kinship system can be more clsarly depicted as fields of network organization extended in the region.
Redfield presented his 'concentric series of circles' and 'eccentric series of squares' as diagrammatic devices to clarify relations between the local community and the more complex society around it (cf. Redfield 1967a on 'A community within communities'). He also asserts that local people view outsiders in terms of the two ideas, distance and difference (1967a: 113). There is however, also a third one, that of issue, task, and meaning. With reference to specific issues, individuals take part in organizational entities that cut across locality as well as other organizations based upon other tasks.

From the viewpoint of the single household, local, ecologic, religious, and kinship systems represent four different social fields, demarcated by distinct patterns of organization, values and symbols, tasks, issues, fora, situations, networks, groupings, and rules for including and excluding personnel. Let us now see how the same personnel are involved in a whole series of fields which display different forms and levels of scale.

\subsection{An ecosystem as a social field}

3.2.1. Its scale and aggregate form

Within the area under study, ecosystems can be delineated by differing levels of scale. Three ecological sectors - dry-larming, nomadic, urban - can be described and then tied together into a picture of the region as one big ecosystem. Within the region, several ecological subsystems can be distinguished, each including numerous villages. Valid units for description as ecosystems are also one or a few villages which take their water from underground or open irrigation canals or isolated wells.

I have chosen for description an ecological subsystem which can be conveniently circumscribed and which represents a resource adaption - canal irrigated agriculture, practised by several hundred thousand of Herat's inhabitants. Water diverted via man-made canals from the Hari-Rud River is here the limiting factor. The stream itself descends from high central Afghanistan, passes westwards through the province of Herat, and then bends to the North, disappearing into the desert sands in Soviet territory.

In the river valley to the east and west of the town of Herat there are several long irrigation canals, one of which I shall describe. Like the others, this canal is simply a big ditch about 40 kilometers long with a width of 10 meters at its source and less than one meter towards its termination point. The essential features of irrigation technology as found today have apparently remained the same for centuries. 
Approximately one hundred thousand individuals live in villages drawing water from this canal. In addition, many people from the drier areas come as labourers during the harvest season. Absentee landlords, in the town and elsewhere, receive their parts of the yearly crops; nomads trek through, pasturing their animals on village lands, taking water from the canal, and exchanging products with villagers; and beggars and others also receive some of the produce. Population density in the canal area thus runs to several hundred per square kilometer - a dramatically different picture from the thinly-populated tracts of scattered villages in the vast deserts and mountains to the north and south of the river.

The social organization of the canals contains several levels of cuordination and control. As outlets from the main canal, smaller irrigation ducts lead to the villages. The source of such a 'village canal' is an opening in the bank of the main canal which has specific dimensions stipulated and controlled by state authorities. A few years before my fieldwork, all such outlets were framed in concrete according to specific dimensions. In itself, this work implies neither modernization of irrigation nor more productive use of water; according to informants, it was simply one of many measures taken within the traditional system of water distribution in Herat.

All land connected to the main canal is denoted and stipulated in an old 'Register of watergiving', kept in the district government's office. Although the district government administers an area larger than that of this particular canal, it has the traditional task of effecting an equal and just distribution of water among local landunits within the canal area. The register pertains to land and water only; it is not a cadastral survey.

The dimensions of the village outlet opening are proportional to the size of the area it irrigates. These are the only legally accepted outlets from the main canal to the villages and through then each village is formally allocated a fraction of the main canal's total water flow. The use of water wheels and motor pumps along the canal is forbidden, since this would disturb the calculated distributiun of water via the fixed outlets.

When one outlet serves two or more villages, water is allocated in periods of hours and according to respective field sizes by opening and closing the gat es to individual neighbourhood ducts leading off the 'village canal'. Irrigation management within the neighbourhood is left to the farmers themselves. For example, villagers "pysint a local 'water giver' to irrigate their rice plots which are nurmally planted in a contiguous village tract and must be flooded dhily during the dry season. Such an authority minimizes quarrels, but he is nonetheless carefully controlled by neighbours. Wheat, on the other hand, is individually irrigated at weekly intervals; this also requires considerable coordination among households.

It is surprising that the number of inter-household conflicts on the neighbourhood level is so limited. On the whole, irrigation rules and routines function to minimize disagreement among the individual agriculturalists using the water. Neighbours in irrigated villages do have their quarrels, but not so much over the allocation of water.

Coordination at higher levels of canal-organization is far more complicated. The whole canal area consists of a complex network of small and large channels, crisscrossing each other by tunnels and bridges still mostly built of stone and brick. These and other constructions frequently break down, whereby even small localized damages can threaten several villages with flooding or lack of water.

If single villages had the organization capacity to mobilize themselves and define their responsibilities vis-à-vis others, matters of canal maintenance might be more readily solved. But in fact canalarea villages facing these critical tasks display a characteristic lack of autonomy and ability to make decisions. Even technically trivial damages emerge as intricate and difficult inter-village, even bureaucratic, affairs. Repairs are rarely undertaken before many messages have been passed between village and district head quarters, district officials have inspected the damages, and soldiers have been sent back and forth with letters and instructions. Finally, the district government orders landowners and sharecroppers to pool labour and money and start working within an announced. deadline.

The role of district and provincial authorities in controlling water-distribution is salient. This function is in fact ritualized every New Year during the annual cleaning of the main canal along its total course. The canal is closed at its source, and one and a half thousand villagers a day are set to work with their spades, under the parading control of the district governor, the military commander, soldiers, etc. - all to the music of village 'Jat' musicians.

The most important types of conflicts in the system arise between the lower third and the upper two sections of the main canal. For several decades now, water has been permanently scarce in the lower third. It seems that, with the presently increasing population density, the canal's irrigation capacity is virtually exhausted before water can reach the terminus. Since all the users of canal water need more than is formally allocated to them, illegal tapping frequently occurs. But people in the lower section have no place to steal from, while their fellows in the upper (wo sections will dig 
holes in secondary canals designed to serve the lower ground. Apparently a moral principle is involved which seems to say, stealing from a stranger is at least not so bad as stealing from a neighbour'.

Due to this dispartity in water supply, important dissimilarities appear between the lower and the upper two sections of the main canal area. In the upper two sections wheat, rice, and cotton are cultuvated, while the lower third, lacking sufficient water for rice and cotton, has only wheat. In drought years, damages are worse in the lower section than further upstream. Land is also cheaper in the lower third of the canal area. It is people of the low section who most frequently address the district government with complaints about water thefts committed by upper section inhabitants and with petitions for improved methods of equitable water distribution.

The government has traditionally tried to equalize water distribution by closing for one day each week all the outlet gates along the upper two sections of the main canal, thus diverting all the water to the lower section. A few years ago an additional measure was introduced. Across the main canal, at calculated intervals along its course, concrete steps were built which keep the water level within each interval at a controlled height. Thereby, the interval levels in all three canal sections could be compared and controlled. The Kabul government ordered the implementation of this new arrangement after receiving a petition from the producers and landowners of the lower canal section.

Huwever, the introduction of these concrete steps did not bring sufficient improvement. In 1970-71, drought struck the entire Herat area and damages remained greater in the lower section than upstream. People in the upper sections also suffered; in both drought and normal years they now receive less water than before the introduction of the 'interval steps'. Some of the higher land tracts in the upper sections no longer receive sufficient water for rice and other demanding crops. Productivity as well as land prices have fallen in these specific sub-areas.

Today's problem is not only one of equal distribution. It is also an overall shortage of water. Traditional irrigation technology in Herat simply cannot supply enogugh water, regardless of how it is allocated.

People in the low section exclaimed to me, 'Since water has come to our village by that canal for two thousand years, why doesn't it come now?' Their own answer was, 'too much theft further up', but the basic answer is that water supply does not increase, while the size of the dependent population does.
This process represents the Herat version of the 'ecology crisis'. Over recent decades the population of the canal area has grown, due to both natural increase and net influx of people from the region's drier parts. Along the water course, the irrigated area has been extended so that today (without any parallel improvement in irrigation technology) more land is drawing water from the canal than only a generation ago. The river and canal yield the same amounts of water as previously, while today more people need water for more land and more grain.

Additionally, we can observe that the effects of a bad harvest on the sharecropper's household income depend upon the ratio between his and the landlord's shares of the annual yield. In any case, water scarcity and a poor harvest will compound the sharecropper's economic losses by automatically reducing his share in absolute terms.

No matter how small the annual yield, the sharecropper must pay rent to his landlord. In Herat this is currently one-third or one-half of the harvest, depending upon whether the sharecropper possesses his own oxen. Although in itself a poor harvest might support the family that produces it, there may well not be enough after the landlord exacts his rent. Since a considerable number of families experience budgetary difficulties even in normal years, it is not surprising that heavy debts among villagers are an integral part of the whole picture (cf. Ferdinand 1962).

As extreme case, whole neighbourhoods in the lower section were deserted during the 1970-71 drought because of the absence of water. People there told me they had never before experienced such a disaster.

In conclusion, some broader organizational implications should be pointed out. By taking part in water allocation from the maincanal, the agriculturalist is involved in the event system of at least three different macro-fields of social organization. First, water is a resource which implicates the irrigation farmer in a large-scale ecosystem. Secondly, the use of water is tied to land as property since water is fractioned out to land and not to producers as individuals. By receiving his portion of canal water, the agriculturalist thereby enters the macro-system of property and class. Thirdly, canal water is subject to state control within the field of public administration. What Wittogel termed the 'law of changing administrative returns': (Wittfogel 1967: 109) seems to apply here in the following way:

Isolated desert and mountain wells and canals are free of external 8 government interference, since it would be too expensive to administer these dispersed water sources effectively. Huwever, 
despite the general scarcity of administrative resources, the compact and densely populated basis around Herat town lends itself to some degree of government control. Thereby, agriculturalists using the canal's water enter the macro-political field and become involved with representatives of the state.

In sum, social events occurring in canal irrigation are simultaneously also events in several other social fields.

3.2.2 Proper dynamics, and some analytic procedures

The general dynamics of ecology display a patterned flow of organic energy. More specifically, we can approach the proper dynamics of the canal irrigation system in the following way: It is an ecosystem where management units in the human population, coesting with each other and with animal and plant species, carry on agricultural production with water as the limiting factor.

Agriculturalists exploit the irrigated fields, and the crops they harvest extract minerals from the soil. It is highly characteristic of this type of agriculture that irrigated fields are neither exhausted nor impoverished. Critical minerals are circulated back to the soil in numerous ways - nutrients are carried by the canal water, strong winds move in sand from the surrounding steppes and desert, and Herati agricultural technology replenishes the soil with plant, animal, and industrial fertilizers. The fertility of canal-irrigated fields has been maintained over years of intense cultivation, invoiving to some extent double-cropping as well.

The amount of water available is, on the other hand, strictly limited. The Herati agriculturalist has considerably less irrigation water than, for example, farmers in monsoon-fed Southeast Asia. Rice cultivation in Herat cannot possibly achieve the immense productivity levels reported for tropical paddy cultivation (cf. Geertz 1970), and local technology excludes paddy nurseries, transplantation, and protracted flooding of plots. Although industrial fertilizer and Green Revolution plants can raise the level of productivity in Herat somewhat, the shortage of water ultimately prohibits any pronounced intensification of agriculture as a whole in the canal area.

Given the present social and technological circumstances, this face constrains the marginal return of labour input on any landplot and the number of consumers that can be fed from it. If the liuman pupulation dependent upon canal area crops, as defined by rules of property, exceeds the feeding capacity of these crops, the whole system functions to exclude the surplus number of people from the canal area or its distribution arrangements. Social mechanisms (cfr. 3.1.1.) simply push these people out - in many cases, to a beggar's life and premature death.

The canal system itself will persist with its highly productive fields as long as a sufficient, but not too large, number of agriculturalists stay to tend it. Ecosystems of Central Asian irrigation agriculture involve harnessing of sunlight, energy transformations, mineral circulation, biomass production and distribution, all in a highly permanent and resistant pattern. It is no reification to say that these are veritably living systems in space and time. Individuals of different ethnic backgrounds enter from outside and become parts of the irrigation ecosystem, but over their twenty centuries of existence, the Herat canals and their social organization seem to have more thoroughly shaped and moulded incoming people, than conversely.

This striking contrast between the permanence of Herati irrigation technology and the relative transience of the involved human population also reminds us of similar properties of irrigation arrangements elsewhere in Asia (cf. Leach 1961, Geertz 1970).

In order to understand ecological proper dynamics more clearly, we need an approach that takes into account not only men's relation to natural environment but also their place within systems of politics and property (cf. Barth 1964: 17).

Today's ecological situation of land pressure and resource scarcity can be fully understood only in the light of social distribution rules defining irrigated land as property, and produce as owner's rent versus worker's payment, thereby dividing the population itself into class categories. The badar ('he who has') and the nadar ('he who has not') relate to ecological resources in very different ways.

The 'ecology crisis' is simultaneously a distributional crisis, because some crucial pre-conditions for the former are of an economic and stratificational nature. An enormous portion of the annual produce is transferred from the producer households to owners and creditors residing largely outside the canal area. In total, much more than the half is exacted from producer households as rent, interest, and other payments to landowners, creditors, and others.

Recent monetarization has also effected the canal ecosystem by replacing some subistence goods with market goods. The state has been unable to counter increasing poverty. Its modest administrative efforts, including a modicum of agricultural extension services, crop and fertilizer innovations, have proved insufficient.

9 Summing up: the field of canal organization is seen to be an ecosystem of a patterned energy flow between a set of natural 
elements comprising the selected niche, and a number of human action units functioning as producers, consumers, and controllers. The system is characterized by proper dynamics of ecological feedback that account for the maintenance of high-yield irrigation agriculture over time. Significant parts of the proper dynamics include the pattern of conflict within the human population, dominated by tensions between inhabitants of the lower and the upper two sections of the canal area; and the practice of centralized administrative decision-making and conflict resolution. The aggregate population interlinked by these dynamics can easily be delineated and circumscribed in terms of the three aspects of scale: numbers, spatial extension, and density. Likewise, there seem to be few analytic difficulties in accounting for the temporal aspect; the individual canal organization appears to be a social field with a durability of probably a millenium or two.

Considering this, I would like to remark on a specific point of analytic procedure. In general, ecologists manipulate scale as a variable in their ecosystem analysis. Ecosystem can conveniently be described in terms of size, extension, density, and durability:

An ecosystem consists of a biotic community of interrelated organisms together with their common habitat and can range in size, scope and durability from a drop of water together with the micro-organisms which live within it to the entire earth with all its plants and animal inhabitants (Geertz 1970:3).

As for the other fields discussed in this paper, empirical circumscription is validly achieved when a systemic interconnexion system, a proper dynamics, is found. The same proper dynamics however, can display themselves on different organizational levels, in a hierarchy of small and large fields organized by the same elementary dimension (cf. Odum 1963: 10).

At the level of the main canal's organization, we found an ecosystem that is large, diverse, stable and relatively independent of adjacent systems. At this level the ecological proper dynamics could be seen with adequate clarity. The isolated canal system is not at all an arbitrary entity; it is empirically a relatively closed system with an inner dynamics and a scale of its own.

We could also describe ecosystems in Herat at different levels of scale. A larger one - at the regional level - might be too diverse and complex for simple description over a few pages. On the other hand, a smaller sub-system would be less diverse than the main canal and represent a less autonomous entity.

The same elementary dynamics - e.g. of ecology - can manifest thrinclves at several levels of scale, although the dynamics themselves become more composite as we go from less to more inclusive and diverse organizational levels. This point is clear enough in the case of ecological fields in Herat; below we will see that it pertains also to other, qualitatively different fields.

The significance of the ecological field within the overall social system in Herat has still not been evaluated. I have tried to describe ecology in a way that shows the proper dynamics of ecology which affect the individual person and the societal whole, and facilitate the discovery of other relevant fields. As an example, irrigation ecology in Herat seems to imply the institutions of property, class, and the state; and the question arises of how to treat these as social fields and evaluate their significance vis-à-vis ecological and the local fields. First, however, let us turn to a field apparently less directly dependent upon ecology and material matters.

\subsection{Levels in religious organization}

3.3.1. A religious field, its scale and proper dynamics

The vast majority of Herati people are Sunni Muslims of the Hanefi persuasion. Their focal ritual practice is the namaz prayer five times daily, and their central forum is the mosque which is found, either small or large, in every neighbourhood. The basic role-set is that of Muslim believers as brothers, and a critical role-solution that of common prayer at the mosque.

Anyone properly performing the purification and prayer ritual is eligible for participation, and beyond this no further conditions are required of people praying together. The praying congregation may consist of three persons, or several thousand individuals related by nothing more than their common Muslim identity communicated in the ritual. This role-set thus represents a tremendous potentiality for bringing throngs of people to prayer and establishing an instant congregation. The role-set is not so effective, when further organizational implications are considered. These depend upon conditions of the locality and other factors not springing from the religious role-set alone.

Every village neighbourhood has a mosque led by a mullah according to orthodox Sunni law (Sheriat). In marked contrast to this element of religious life are those people who choose the mystic way (tariga) to God, in a Sufi sect or order, led by a sheikh.

Here the basic role-set is that of brothers within the 'circle', of disciples under the 'guidance' of the Sheikh. I will briefly skelch the forn of role-set and network organization in the Sufi tariçat, its aspects of scale and time, and its proper dynarnics of religious sign production and communication. My intention is to discuss 
whether such a religious grouping can be seen as a social field of its. own.

At one level Sufi tariqats are categories including quite large numbers of people. As an example, the Naqshibandi Sufi tradition is found in many Muslim countries. People I stayed with in Antalya were Naqshibandi as were the Sufis of my main fieldwork locality in Herat. There are probably millions of people who refer to themselves as Naqshibandi, but the meaning differs: indeed, it is an open question what kind of relations, if any, exist among Naq̣shibandi people in various countries. At this level we are talking of an aggregate of empirical codes and conmunication practices distributed within a population in space and time. The entity has scale aspects; theoretically, it could be represented on the kind of maps made in linguistic or religious geography. The empirical unit is something similar to a language 'community' - that is, all the people of various countries who to some extent practice the Naqshibandi codes. This is roughly analogous to a scattered population of individuals who speak the same language. But at the level of interaction, a tariqat in Herat has the form of a 'relatively bounded network-organization'. Membership is based on personal discipleship under the leadership and guidance of a sheikh. Disciples come from various localities in the area, since tariqat involvement does not spring from membership locality. Some sheikhs live permanently at one place, e.g. close to the shrine of a saint. Others set up quarters for limited periods in one locality, then move to another. The centre of the sect's life is the sheikh's residence, with a room for the mystic aikr ritual performed by the circle of Sufi brothers.

A successful sheikh develops his reputation in the area, and disciples bring new recruits via relations of kinship, acquaintance, and so forth. In the field I saw villagers become members of a sect under a sheikh who had established himself in the neighbouring locality. I got the impression that the number of active members in such a sect organization tends to be limited. I would estimate there are between 200 and 300 more or less active disciples under one sheikh. Sheikhs rarely manage to build up a large number of adherents; the following processes brake the growth of tariqat organization.

A sheikh has competitors: not only other Sufi sheikhs, but primarily the mullahs of the mosques and Koran schools. The mulliah versus the sheikh, 'Sheriat contra Tariqat', represents a c'asic conflict still played out in Herat.

The prozelytizing sheikh thus breeds opposition to himself, and this is part of the reason for his transicncy. When he becomes. involved in life at one place, it is difficult for him to maintain any exalted position. However, when he moves, followers find it costly to visit him.

Another point probably related to the small size of the tariqat group is the unimportance of literacy which I observed in Herat Sufi life at the village level. Villagers are generally illiterate, both secularly and religiously (Arabic), and much more so than in Antalya. The way to Sufi spiritual fulfillment passes through individual exercises and participation in the circle of brothers, where face-to-face contact is the mode of communication.

Problems in the routinization of a tariqat are salient in connexion with leadership and succession. Finding a worthy successor is difficult; if he is found, there is the danger that he may take over too early or move away with part of the following. When a sheikh dies, the tariqat milieu tends to fall apart as an ongoing concern. The group's life span is limited.

An area may have several years of hectic Sufi activity under a sheikh, and then pass into a period lacking any tariqat group activities. Eventually, a new sheikh arrives with a slightly different ritual repertoire, and some of the old sheikh's followers will 'go to' him, while others will not. There will be significant continuity in the use of ritual idioms, but not in the life of unified groups.

This may very well be the micro-level process underlying the distributional pattern of Muslim Sufism in Central and Southwest Asia: Sufi idioms and practices are widely dispersed, but the practicing groups organized around sheikhs tend to be small and fairly localized.

Any sheikh can thus draw upon the rich inventory of Sufi idioms found among people in an area with centuries of Sufi tradition. The Naqshibandiye 'way' is part of this idiomatic inventory from which any sheikh can select elements, which he then combines in his own way creating a specific style and presentation for his followers.

In sum, Sufism as an inventory of idioms and sign practices is a widely spread tradition, a symbol language known by millions. But at the level of active groups, tariqat units in Herat are small and short-lived.

The proper dynamics of this religious field can be shown in the following way. A tariqat network developes around a sheikh while his career as a Sufi leader develops and disciples are recruited. For participants, tariqat membership is a fairly well-defined thing, and being a Sufi brother under sheikh so-and-so, implies a clear social identity. Via the role-sets of the tariqat organization, rather exclusive information circulates; and by using the specific ritual idioms, members are marked off from non-members. While 
disciples aspire to Sufi fulfillment events are staged and discussed within this entity of interlinked personnel. By means of network links messages are communicated, rituals are staged, and gifts presented to the sheikh who redistributes them while entertaining members. Group boundaries appear emically in rules for the inclusion of disciple members and exclusion of the unworthy and sceptical. The organization works as long as the tariqat role-sets are activated, and as I have indicated, displays the phases of proselytizing, recruitment, and grow $\mathrm{t}_{1}$; difficulties in routinization decline, and dispersal - parallelling the career and death of the sheikh.

The core of the proper dynamics pertains however, to meaning and signification. Tariqat ritual (' $z i k r$ ') is the staging and production of specific symbols defining the inclusion of participants in the circle of brothers. Being within the ritual circle is a symbolic medium for seeing oneself as part of God's greater reality. The disciple leaves the everyday world and moves into the circle of brothers submit ting to a sheikh and a sphere of specific meaning. The acts are mystic exercises, sermons, silent prayer and meditation, rhythmic exclamations (e.g. 'Illallah' - 'Illallah' or 'Allahu' 'Allahu') and extensive series of vehement bodily movements with hundred in a series.

The ritual passes through stages, from a quiet introduction to an ecstatic climax, after which the group falls back into silence; this cycle is normally repeated several times during one evening. Some individuals display ecstasy more intensely and for a longer time than others. A kind of part-whole meaning seems to be important. Actors move in and become parts in the ritual circle. Emically, the bow in zikr ritual is 'abandonment' ('Islam') of oneself to God, and the ritual whole is a medium for coming close and 'seeing' God and eternity. God is signified in the ritual, and for the actors that do the signifying, the signified entity becomes clear in the $z i k r$. The group of actors produce a sign that denotes an entity (God). According to their code, the signifiers themselves approach that entity, which they envisage through their own signification. This signification is achieved by techniques which the novice must strive to master. But the trained and gifted Sufi transcends preoccupation with such rules and comes close to the signified divine entity in a display of ecstatic behaviour. This is a special case of establishing signs in social process (cf. LaBianca 1976).

A Sufi brother said to me after a zikr meeting, 'Our everyday life and misery do not count. God is important'. I understand this kind of religious despisal of the temporal world as a reflex of the ritual signification itself. When an individual's whole involvement in the group ritual signifies God and the relationship between God and man, he literally sees himself as part of eternity: everyday misery becomes a dull reflection of the meaning in ritual.

The characteristic element of these proper dynamics is then one of signification, of sign production and communication. This process underlies the specific form of the tariqat milleu and organization and makes it a relatively bounded system of interconnected personnel, a field with proper dynamics and a scale of its own.

\subsubsection{Scale levels in religious organization}

Within Afghanistan there are hierarchies of religious fora and leaders. One might depict central versus peripheral fora in religious communication and study the circulation of idioms, drawing on analogy with the model of universalization and parochalization, developed for India by Marriott (Marriott 1969).

In Herat, higher rank mullahs and sheikhs are found in and around the city. It would be wrong, however, to see religious hierarchy as homologous with the region's locality structure. Religious networks criss-cross the other fields. Many types of religious personnel are involved: mullahs, sheikhs, students, and dervishes.

The annual cycle of Sheriat mosque life takes place within at least three levels of organization. Everyday prayer takes place in the small neighbourhood mosque (mesci). The main Friday prayer and sermon in Sunii Islam can take place only in a larger mosque (cami) equipped for that purpose; such a mosque must be placed in a local community of more than 40 households. On Fridays, Herati villages therefore leave their inmediate neighbourhood and go to the nearest 'Friday mosque'. For the celebration of the feast of Eid at the end of the month of Ramazan, the nien of many villages come together in numbers of 1500-2000 to pray under one imam.

I leave open the question of how to treat these levels in terms of fields. Instead I will ask whether the international community of Muslim believers can be seen as a social field, and if so, whiat are the critical enpirical criteria for answering this question.

Occasionally events occur which after some time, via chain reaction and repercussions, seem to affect Muslims in different parts of the world by activating international Muslim debate. Through their careers certain individuals have accomplished this: for example, Jamal-ud Din al-Afghani travelled in India, Egypt, Turkey 
ism. In the late 19th century, pan-Islamism was a theme of debate among elites in the Ottoman Empire and elsewhere.

During the 19th century, Muslim leaders started to argue for Islam's superiority over Western science and technology. I was surprised to find myself involved in that debate with Turkish villagers. I was amazed however, when illiterate Herati peasants invited me to the same discussion in practically identical terms. I also find astonishing the similarity in arguments for the purification of Islam which I heard in Antalya and Herat, and for example in Java as reported by Geertz (Geertz 1957).

Communication of ideas within the international Muslim community occurs via fora like Mecca and less important shrines, the printing press and other media, top-level Muslim meetings, and through the networks of imams, sheikhs, and others. Events occurring in one part which effect other large parts of the system, would indicate the existence of a community. As examples: What were the repercussion of the Galiphate's downfall in Muslim countries? Of Atatürk's struggle against the Great Powers? Of the Arab-Israeli conflict in its various stages? Such events are discussed among the elites of various countries, sometimes even in village mosques and other peripheral fora.

If relatively bounded systems of inter-communication exist, the notion of social fields applies. We can describe people's religious activities as being part of several levels of religious organization, i.e. hierarchy of small and large fields. Such an analysis would be in the tradition of Kroeber, Redfield, and others, who have been engaged in the anthropological study of civilizations as coherent wholes. Much of the empirical work belongs to other disciplines, but the overall picture and the analytic discussion of forms and processes are anthropological themes.

\subsection{Small- and large-scale fields of citizen-state interrelationships}

For relations between citizens and state agencies, the units can be delineated in the same way as done for locality, ecology, and religion. Again I start the description with a number of agricultural villagers as the selected personnel set.

Villagers relate as clients to landowners, traders, saints, and others taking roles of patronizing middlemen. The low class client offers electoral support, material payment, and the promise of prestige, in return for the middleman's addressing a state agency to elicit decisions and resources in favour of the client. In Herat, the patron-client relation is not always a multiplex and personal me. There is a kind of political market: middlemen are sought due to reputation, and they compete with each other for support and renumeration.

The middleman niche is made possible by the distance between bureaucracy and village people. The former lack resources to govern the population effectively, and the latter lack both the codes to deal with officials and a platform based on local or other organization.

The canal organization is a case in point. Great numbers of villages experience the same troubles, which they cannot handle themselves. A landowner can patronize them by persuading the administrating to take action. Grain distributed by the government as aid to the drought-stricken agriculturalists in 1971-72 was channelled largely by informal middlemen rather than through the channels of provincial bureaucracy.

As for scale, a reputed middleman may have a considerable number of actual and potential clients in need of his services vis-à-vis the state or in interpersonal conflicts. The villager-middlemanbureaucracy connexions are institutionalized, operating as cases of social organization with a degree of closure and permanence.

The proper dynamics in question pertain to the flow of demands and services between citizen and state; taxes, military service, expressions of loyalty from people to government; regulations, claims for loyalty, and aid from government to people. The process is one of feedback: i.e. a cybernetic order (cf. Deutch 1963). This process is an aggregate and composite one. At its core lie the more elementary distribution of power and autonomy in the patronclient relation, and the recruitment and mobilization process through which the patron builds up a power enterprise using strategies in local-level and central fora (cf. Bailey 1970; Eidheim 1971, chs. 2 and 5). A political field in Herat can be seen as a set of such enterprises and governmental agencies, in relations of competition and alliance. In everyday life, the effect is that the citizen role is drawn into such political relation and is moulded by them. The characteristic aggregate feature is that of an administration unable to govern villagers effectively by bureaucratic rules, and villagers unable to articulate their interests according to class or locality rules. With respect to this dimension involving the state and politics, the same personnel in Herat are part of a series of less and more inclusive fields of varying levels of scale. 
3.5. Regional organization as a social field

3.5.1. Why study the regions, and how to find them

Above, I have argued for a multi-field analysis and stressed the point that specific fields should be studied in the context of their interrelations, not in isolation or for their own sake. Turning to the theme of regional organization, we must delineate the 'region' by demonstrating both its characteristic attributes and its interconnexions with other fields of different scales.

The various specific fields do display a certain autonomy as systems, since the dynamics of qualitatively different fields cannot be reduced into each other. Nevertheless, the fields do effect each other, and some kind of economic dynamics seem to influence the functioning of all of the fields discussed so far. These dynamics are thus especially critical for understanding the whole set of fields. But we have not so far discussed the nature of the economic dynamics. To obtain their proper characterization, we need a new empirical picture displaying the concrete form and aggregate pattern of the production and circulation of economic values in Herat. From there we can search for the relevant field, delineate its scale, and try to identify its underlying dynamics. The first question is, in which empirical area should we start looking for the field of economy?

Since the same elementary dynamics can be manifest at several organizational levels of scale (cf. 3.2.2.) we could alternatively describe household, locality, or some other unit as economic systems. It is now wothwhile, however, to consider a really great number of people dispersed in the Herat landscape, and investigate the possible effects of the economic interconnexions within such an cntity. A bird's-eye-view of a large entity with its elements can more conveniently show the characteristic features of the composite economic organization in Herat: its forms of labour division, productive regimes, modes of circulation, and economically based stratification. The single actor and household must be understood as part of such a larger system comprising the different but interrelated economic sectors of agriculture, pastoralism, trade and crafts, as well as a number of social classes and forms of status groups. We can further observe from the above description that the great differences in wealth and stratification in Herat do in fact jresuppose a large population size. Finally the picture of a large field will conveniently display the nature of local-global relations, the interconnexions between life in Herat and the macro-levels of intimal and international economy and politics.
I will choose the level of 'region' in Herat to make clear these features and dimensions. A region can be defined in many ways. Cultural geography and 'regional science' provide many viewpoints, which cannot, however, be dealt with here (cf. Isard \& Reiner). Initially, it is difficult to know to circumscribe a region, or by which principle to define its organization. Like 'society' and the other units discussed above, regions must be discovered before they can be defined. Where to draw its boundaries is something we know as the result of investigation and not prior to it.

For comparative purposes, the concept of 'region' cannot primarily or exclusively be defined in economic terms. In some societies, the dominant regional dynamics is apparantly effected by processes in religious communication, although Islam in present-day Herat or Antalya does not work in that way. As another example, the effects of state decision upon people's everyday life in Scandinavia are many and formidable; to a large extent, state activities structure regional organization there (cf. Brox 1966). As an intermediate case, Turkish state activities more decisively affect regional patterns in Antalya than the Afghan administration influences Herati regional organization (cf. Grønhaug 1971; in press). But in both cases this is less pronounced than in Scandinavia where state bureaucracies mould and re-mould regions within their respective territories.

In anthropological literaure the concept of 'region', when defined, is normally used as a synthetic or syndrome concept. It is difficult to conceptualize 'region' for the purpose of comparative analysis. In any case, defining regions in terms of physical geography or administrative divisions is irrelevant, prior to an analysis of social organization in the area (cf. Barth 1966a). Forms of regional organization and attendant processes differ among societies. In each case, we have to find out which dimension is dominant in the pattern of regional organization. By now we can, however, take clues from the analyses of the smaller fields in Herat which indicate the importance of the economic dimension.

At the level of phenomena, a regional picture should show a hierarchy of large and small localities, and a patterned flow of personnel, produce, services, and messages comprising an organization which ties together people from the constituent localities. A hypothesis about regional organization deserves attention, if it points to some simple principles that organize the whole of a large population into distinct categories of people, displays some signifi-

14 cant interdependencies between these categories, and accounts for the hierarchy of localities in the area. 
3.5.2. Analytic procedures

I will consider the Herat region as a field of relations among the spatially distributed main categories of personnel within the area around the town of Herat which includes my focal village. The region will be described as an organizational field for the distribution and circulation of land rights, labour, animals, produce, and services in trade and crafts.

The personnel categories of 'farmers', 'nomads', and the like, are aggregates which I have constructed through observations of households and other micro-phenomena. The main procedural steps from the micro-level to aggregate categories and their regional interconnexion can be outlined as follows.

Initially, I map the main types of economically relevant units households producing wheat-and-rice versus only-wheat, long distance versus locally ranging nomadic households, landowner families, business firms, public offices, shops, and so forth. They are described as decision-making and action units, each type possessing a specific personnel and resource inventory and a characteristic dyriamics of organization. I summarize by aggregating my material into a larger universe of description, displaying the total variation of main forms of units, and making an over-all estimate of the respective numbers of different types of units found in the region. (Cf. Barth 1966a).

Following events and processes, I generalize from case stories to show the characteristic organizational dynamics within the different types of units. I study these units both in isolation and as elements in the larger whole which have been affected by over-all regional change during the last decades. The different unit- and sectoranalysis are then combined into a dynamic picture of aggregated inter-unit relations. At this level we need additional data on the forms of encounters and confrontations arnong units of the different relevant categories. During fieldwork I was able to conceptualize these inter-unit relation pattern and tried to observe as many as possible of those types of encounters which manifested intercategury relations. Moving around in the area to map unit- and inter-unit behaviour, I was in fact beginning the analysis of regional organization. In the analysis proper, I try to simulate how initiatives from one unit result in counter-moves from other similar and dissimilar units, producing patterned series of chain-reactions and repercussions. By tying together several sub-systems via their ferellack-interconnexions, there emerges a generalized picture of

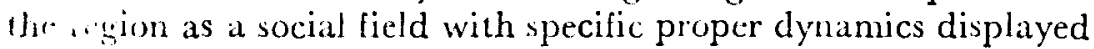
1....ugh the simulation exercise, and with a scalc equivalent to the size of the population that appears to be organized by that dynamics.

At all levels, data on social events and social event analysis are critical. And finally, as part of simulating regional organization, I present analysis of a regional 'macro-event' that displays the characteristic features of regional organization as an entity.

3.5.3. A short description

The urban-rural relationship is a significant element in Central Asian regional organization. The urban centre in this case is Herat (cf. English 1973). Although accurate population statistics are lacking, it is reasonable to estimate about 100,000 inhabitants for

Herat Gity. It relates to its hinterland by trade via the bazar and by contracts between urban landowners and village sharecroppers. With its present boundaries the province of Herat includes about 40,000 square kilometers, whereas the city's actual hinterland, which also includes parts of the adjacent provinces, totals roughly 60,000 to 70,000 square kilometers. And we can assume the corresponding population is approximately one million people, which represents an average density of about 15 individuals per square kilometer. In fact, density varies dramatically from a few individuals per square kilometer in the arid areas to several hundreds in places irrigated by the canals.

As for the hierarchy of localities in the Herat region, there is one big city and a multitude of small rural communities. The link of the 'town' between city and village is weak - following my impression, weaker than in Muslim parts of the Mediterranean area. In Herat, the towns of this intermediate size typically consist of some public office buildings, shops, and residences, while in their overall composition they appear as big villages. The essential regional picture is then that of Herat City as the core, with lines of transport, control, and communication passing directly into rural localities.

The estimated population of one million can be categorized as follows:

1. agricultural producers:

1.1. agricultural producers with water for wheat only,

1.2. agricultural producers with water for both rice and wheat;

2. pastoral nomads staying in or passing through the Herat area.

3. people with their main affiliation to the city:

3.1. landowners, big traders, administrators,

3.2. small traders, craftsmen,

153.3 . daily paid labourers, urban 'Lumpenproletariat', and very few migrant labourers. 
Roughly, these categories represent the following percentages of the total population: 1.1. $-50 \%, 1.2 .-30 \%, 2 .-10 \%, 3 .-10 \%$. This distribution is persistent, although individuals may pass from one category to a nother.

The mobility of people in Herat nullifies any attempt to isolate definite regional boundaries. Recalling the problems of describing local community, religious and ecological organization, we find it similarly difficult, in terms of empirical phenomena, to circumscribe a 'region' as a concise unit. But, proper dynamics as an abstraction can be more clearly defined. I shall attempt to disclose these dynamics of the region by portraying what happened to people in Herat during the drought of 1971-1972, showing how relevant occurrences in different parts of the region were interrelated during the course of this pervasive event.

The 1971-72 drought meant that annual precipitation was reduced by a few inches. The following picture demonstrates the sensitivity of the whole of social organization in Herat to even small ecological fluctuations.

The drought affected differently the various categories of the 1) population. For those agriculturalists who normally have enough water for both wheat and rice, the 1971 wheat harvest was essentially equal to that of normal years; water supply remained adequate for weekly irrigation of wheat. The cotton crop of these producers was also average. Contrary to fluctuations in wheat prices, cotton is purchased at stable prices by a state controlled monopoly: in 1971 many producers received for this crop a money income typical of normal years. But rice crops were meagre in almost all villages in the region. A good year's return is 15:1 (yield:seed), while 1971 yields only trebled, doubled, or gave no return at all on seed.

Therefore both producers and owners suffered a serious loss of income; this represented especially critical consequenses for sharecroppers. In 1971 many such households could not meet family necds with their shares of the harvest; they had to take up loans to cover the deficit. Villagers are normally in debt; the drought increased the debt of poor villagers and made it more difficult for them to repay loans, since another year's postponement leads to increased interest rates. Imbalance of household budgets due to loss of income and insufficient credit forced many to sell their oxen to obtain food. Only people possessing their own oxen can work as 'fifty-fifty' sharecroppers. The loss of one's oxen thus leads to a luwer socio-econonic position; sharecroppers without their own ixen receive one-quarter of the harvest or much less if they work on at daily basis.
2) The misfort unes of those normally producing only wheat were even greater. Many such fields were parched both years; at best, they showed trebled investments in seed. These people also lost an additional source of income. In normal years they work for rice producers as seasonal migrant labourers. When their own wheat harvest is over, they move to the irrigated areas and cut rice for a share of the crop. The drought and reduced rice crop eliminated demand for this labour force. In those very few wheat-and-rice villages where rice yields were close to normal, some labour was needed. But since the supply of labour vastly exceeded demand, wages for daily work were depressed to an extraordinarily low level throughout the region. People seeking work filled the paths and roads of Herat.

In order to survive the critical months, villagers sold their oxen, took up more loans, sold household furnishing and women's gold, and started petty trading with these and other items. Beyond that, begging was one of the remaining alternatives.

Pastures used by the nomads are generally public land owned by

3. the state. No fees are paid for the use of summer pastures in the mountains, nor do specific tribes monopolize territories. Distantly ranging nomads winter in the western and northern lowlands, close to the Iranian and Soviet borders. Some nomads own land and water resources there, though most land is public. Passage through village districts and pasturing on agricultural fields are normally free of charge. But, the conditions vary for grazing in agricultural areas; fees are sometimes demanded. Many nomads follow itineraries, lasting up to 40 days, which pass from western or northern lowlands up to the mountains of Central Afghanistan, while others have short routes of a few days duration, which lead along the slopes north and south of the Hari-Rud River. Households and camps change the direction and length of their migration routes according to changes in flocks and qualities of pasture in the various areas.

An exclusively nomad household needs a minimum number of animals in order to keep a balanced budget. The necessary number of animals, and the general opportunity situation of the nomad household, must always be considered in relation to the continually fluctuating prices in non-nomadic sectors of the economy, especially the price of wheat.

Pastures were decimated during the drought. Sheep and goats became thin, producing a less than average amount of wool. Extraordinary amounts of animals and meat were offered for sale. 16 Since wheat was scarce and expensive, the exchange rate of animals and animal produce for wheat fell drastically in the nomads' disfavour. Although this exchange rate fluctuated from month to 
month, the overall trend described here dominates the wheatmeat-relationship for one to two years.

Observing this crisis in nomadism, one might expect a gross migration of nomads to villages and the city. Significantly, this did not happen. Most nomads successfully survived the critical months without abandoning pastoralism. They managed in different ways.

Those nomads ranging closer to Herat City cut brush in the descrt, transported it to the city on camels, and sold it as fuel at prices inflated by a drought-caused scarcity of fuel. Similar to villagers, nomads engaged in petty trading in animals, carpets, and household furnishing. But pastoralists did not switch to agriculture villages were already swelled by ranks of unemployed agricultural wokers - nor did they settle as proletarians in the city. Rather, they reduced consumption, lived from their own animals, and took up loans - for example, from wealthy relatives settled as landowners and traders. Although their flocks were reduced, they lived through the crisis as nomads. Finally, the winter of 1971-1972 brought eiough rain to assure better pastures. The rain meant a new possibility to re-build herds to an adequate or better level of wealth than before the crisis. Throughout the crisis, this prospect remained more promising to the nomads than turning with empty hands to some other sector of the region's ccononiy.

(1) In the city, economic activities were depressed. The city of Herat is extremely sensitive to economic fluctuations in the countryside, since its activities are largely financed by the transfer of produce from villages. Many traders and administrators are also landowners, and one general effect of the drought was a gross reduction in the income of property-owners residing in the city. This had the further effect of a reduction in house construction, which is a main source of wage work in the city. Since crops had been reduced, wheat and rice: straw became scarce on the market. This left brickmakers without their normal fuel supply. This important building material thus became scarce and exceptionally expensive; the city's brickworks decreased their output. With rising construction costs and dwindling personal incomes, the upper class people of Herat built less during the drought. As a result, there were fewer jobs and less income available to wage workers.

In normal years, wage workers are also employed in the city to pack pistachio nuts, raisins, wool, and other produce. All of these activities are tied to the agricultural sector; and in all of them the demand for wage labour decreased. As a further repercussion, most traters dealing in agricultural goods had their business reduced, so that the need for porters in the bazaar was diminished.
In general, total regional productivity, including services and wholesale and retail trade, decreased during the drought.

We have secn liow the drought had specific implications for the various categories of personnel: how landowners, workers, peasants, nomads, and others suffered to different degrees and by different mechanisms. One overall effect should be underlined: the systems production of poor people. Many households are economically marginal, and the drought had the effect of pushing them further down the socio-economic ladder. A clear manifestation of this was increase in the number of beggars - male and female, old and young, ill and healthy.

On the other hand, some people benefited from drought. They were the people who control a big enough surplus to influence grain market prices, to grant interest loans, and to buy land. During the crisis they sold grain on a seller's market and bought land on a buyer's market. Other property-holders without such savings suffered from the crisis and emerged less wealthy, selling land to cover expenses.

Summing up, the regional interconnexions display themselves as a on-going field system. The empirical pattern is seen in the network relations and the channels for econonic resource flow in production, trade, and on the labour market. I have described the dynamics of the agricultural, nomadic, and urban economics, and the dynamics of the regional econony as a higher level system intercomnecting the three. This is the proper dynamics of the regional organization in Herat, tying together the population of one million people as an organized entity.

Looking outwards, the regional picture enables us to relate life in Herat to larger fields, e.g. fields in international political and economic relations. Two important things have happened in Herat during the last fifteen years.

Firstly, the USA and the USSR have built an extensive road system by which Herat has become connected with most of Afghinistan's other cities and also the surrounding forcign countries. Secondly, economic life has become more monetarized. Especially in connexion with development aid from abroad, money, mainly from the two biggest powers plus Western Germany, has been pumped into Herat via Afghan state channels (cl. Ministry of Planning 1970, sections on 'Money and Banking', and 'Prices'). The region, and its multitude of households and ecological and other sub-systems are thereby more directly comected to international price fluctuations, in a way completely beyond the control of Herati people. This is one specific tie between Herat and the national and international systems by which factors 
from the outside are channeled in as determinants within the region itself.

Up to the time of my fieldwork, no concomitant industry had been started in Herat, and the level of improvement in agriculture was low. Herat still has no hydro-electric or other power plants designed for supplying industry.

Trade on all levels, however, has been increasing, and more business goes on in Herat than in earlier decades. When it comes to distribution of wealth and the creation of new jobs for the increasing population, it is an open question whether this means real development. Monetarization means that the villager substitutes household products for goods largely imported from abroad (e.g. clothes). Surplus from trade cannot yet be invested in industrial enterprises in Herat; wealthy people transfer their profit from Herat trade and agriculture to Kabul and elsewhere where money can be more profitably invested. An improvement in the power and transportation situation should change this pattern.

With prospects of financial support from Iran, a railway is being planned. Like roads and money, a railway may transform regional activities, as well as organizational patterns in agriculture, locality, and other fields.

\subsection{An economic field}

From the description of the region we can now identify those economic dynamics that tie together the regional population. The Herat economy comprises the activities of people dispersed within and around the city. Moving within this large geographical area, people pursue their economic alternatives. Many landowners residing in the city use profits made in one village for investing in additional land located in other parts of the region. Producer households sinilarly circulate within the area, following changes in their opportunity situations.

At the level of phenoniena we have been describing regional organization. But in the course of analysis, regional form has itself appeared largely as an epiphenomenon of economic processes. If we now disregard specifically regional features, the hierarchy of localities and spatial communication network, and focus instead upon the processes of economic production and circulation, we can envisage the above picture as an economic field. The regional entity is large enough to display a sufficiently permanent and autonomous economic system which adequately represents characteristic productive regimes and social strata. This economic field includes different productive regimes and modes of distribution. The former include pastoral nomadism, agriculture and crafts, and a number of sub-types such as irrigated and non-irrigated agriculture, and pastoralism combined with the collection of fuel. As a main point, the relation between labour input and productive results differs in these various regimes. For example, we saw the contrasting ways in which nomadic and agricultural households coped with the drought.

The impoverished nomad can realistically hope that his reduced herd will regenerate to a level sufficient for maintaining an independent household and a satisfactory standard of living. The dispossessed agriculturalist has no analogous opportunity for again attaining wealth. His income will be restricted by the rate of remuneration for his labour and the ratio of workers to consumers in his household. One aggregate result of this difference is a contrast between the elements of stratification generated in the nomad and the agriculturalist sectors, respectively. Common macro-factors imposing themselves from national and international fields will bring forth dissimilar effects in the two sectors.

One important mode of property distribution is that of the independent freeholder who as producer and owner controls his household's means of production. This mode prevails in the nomadic regime (though modified by an element of debt among nomads), and among urban and rural craftsmen as well as traders (family shops). In the agricultural regime, peasants of this type are nowadays found mainly in the peripheral and less productive parts of the area. Most of the cultivated land in Herat is in the hands of non-producers. Some sharecroppers own a little of the land which they work, while the rest is controlled by landlords. The domination of landowner/worker relationships in agricultural production and distribution has implications for the overall economic field in Herat. Surveying the economic field for the dominant mode of distribution and circulation, we are impressed by the overall prevalence of market relationships. People are related to land via the market as buyers, sellers, and renters. Villages often resemble a kind of agricultural factory where dwellings serve merely as workers' quarters. Local agriculturalists seldom elaborate symbols which identify their families with the land - a trait so typical of 'proper peasants'.

Most significantly, the landowner/sharecropper relationship is itself market-oriented and part of the overall market. Sharecropping contracts are annually renegotiated, and labourers are continually competing for sharecropping rights and wage work. As a feature of the regional market, the ratio of landed property requiring labour to landless labour secking employment determines the level of 
landowners' rents and sharecroppers' remuneration. In recent decades labour supply in Herat has increased faster than the area of cultivated land. Since labourers underbid each other, their pay shows a relative decline in terms of produce per unit of labour.

The market relationship between landowner and sharecropperwage worker dominates both this sector and the overall field of economic production and circulation in Herat.

Three important features for characterizing this type of economy should be noted: First, a great number of the production-consump(ion units in the Herat economy are family households, and many aggregate features of the overall economy are generated by these domestic units. This is obvious if we consider the nomads and various types of family firms engaged in trade and crafts. This point is less clear in agriculture, due to the dominance of non-producing landowners. But since a large number of work decisions are left to the producer households, even this sector has many characteristic features brought about by the domestic units. Without pursuing details, I would say that as part of the overall economic field in Herat, there is an organizational element we may call 'domestic' or 'peasant'.

Secondly, the market-oriented landowner/labourer relationship as the dominant feature of property distribution and control in Herat is vital because it determines the intensity of producers' work, the division of production, the expenditure of income, and the levels and patterns of investment. Landowners use a substantial portion of their income to maintain themselves as a kind of leisure class; that is, to maint ain and raise family status, notably through conspicuous consumption and education. Herati landowners do not substantially invest their income in the improvement of agricultural productivity.

Finally, we can observe a capitalist element. The allocation strategy of 'money-commodities-money' is the core of trade in Herat. Many landowners channel agricultural surplus into trade, money profits and further investments following the same pattern. Suecess stories are told about numads who have turned profits from pastoralism into land and trade, thereby becoming big landowners and traders in the city and, in some cases, founding family firms operating on national and international levels. But these stories usually follow a course which takes the entrepreneur to Kabul and other places outside Herat.

The reason for the stagnant capitalization of economic life in Herat cannot be demonstrated within this paper. I will only point to the constraining effects of the landowner/sharecropper relationship itself. While the landowner consumes a portion of his income, the remainder can more easily be turned into profits via trade and entreprises outside Herat, than through investment in local land worked by sharecroppers and oxen.

In sum, economic life in Herat is market-dominated. In this specific sense, relations of production and distribution contain a critical capitalist element which should not, however, be associated with 'mature capitalism'. I have accounted for market dominance in Herat by referring mainly to the specific traditional and domestic conditions of that region and Afghanistan. It would be false to attribute this market dominance to effects of the international capitalist system. Although I have pointed out some recent changes implying recent stronger local influence of the international capitalist system, external economic inputs have until now had comparatively little effect upon economic life in Herat. Nor have I implied any necessity for capitalism to become increasingly dominant in the future development of socio-economic life in Herat. We can imagine other paths of change.

\subsection{The question of one field dominating others}

We may now raise the question of the relative dominance of one or more of several interrelated fields. Here we shall empirically discuss the hypothesis that the economic field is especially determinative within the set of fields presented above. We have gained a general impression that the dynamids of the market in circulation of land, labour, and produce are strikingly unhampered by nonmarket elements of the economy and by the proper-dynamics of other fields.

The same personnel take part in all of the fields described. When a person participates in the Herat economy he acquires social roles that determine or steer further allocation of roles to him as he takes part in other fields. His economic role and the opportunities implied by it determine the level of resources in his domestic unit, his platform for taking part in locality organization, his access to and control over land and water, his manner of relating to state agencies, and in many ways also his involvement in religious organization. Hence, in the construction of the social person in Herat, the labels of sharecropper, freeholder, landlord, trader, craftsman, nomad, and so forth, do not refer merely to occupational roles. They imply entire clusters of roles, opportunities, and attributes. The social allocation of other roles is steered by the operation of economic roles and role-sets.

Thus, the overall organizational potential of Herati (1) local communities and (2) kinship organization does not fully materialize. This is due to people's residential instability, which in turn is caused 
by determinants in the sharecropping economy. The effects of (3) the ecological crisis in Herat can only be understood when we consider economic organization; it was the mode of property distribution that worked so as to let the drought - an ecologic phenomenon - create food-scarcity to a major part of the population. (4) The Afghan state's administrative poverty is partly explained by the organization of the econony - e.g. the hopeless task of collecting taxes from traditional Afghan agriculturalists and pastoralists. It is more pertinent, however, that the actor's role in political patron-client relations is conditioned by his economic situation. Reiidential instability also markedly restricts any effective contacts between state agencies and villager households, and negates efforts of individual households and civil servants to build up mutual working relations. The state interferes in canal irrigation, but merely as a kind of arbitrator in intra-canal conflicts generated in an economic-ecological system that operates rather independent from the state. As for (5) regional organization, its gross features appear as veritable epiphenomena of underlying economic dynamics within which the landowner-producer relationship is a highly dominant element. The regional account shows even more clearly than the description of locality, the vehemence of economic forces in Herat and their maisive and composite effects. Finally (6), economic determinants allocate to actors in Herat differentials of power and resource control, placing them in highly different life situations, thereby effecting people's involvement in religious milieu and the mode of religious communication itself. The symbols of Sheriat and Tariqat Islam were not originally made in Herat; other people use them elsewhere under highly different circumstances. But the emic meaning of these symbols is produced from the context of Herati people's economically dominated life.

At the level of status and role, the question of inter-field dominance can be seen as a matter of determinative or 'imperative' roles: one role-type, when allocated to an actor, then steers him to the further allocation of roles (cf. Barth 1969). The processes and intensities of steering in role-allocation comprise a theme that must be studied empirically: we can do so by following the respective fields' relative effects over time upon role-allocation in the social construction of the social person (cf. Grønhaug in press; part III).

We can empirically follow the processes of inter-field dominance by studying the role transformations which occur as the actor moves from arena to arena, from field to field. In the case of Herat, we can see how the actor's economic roles imperatively effect the social allocation of other roles to him.

When analyzing this theme, we must distinguish among three levels: the person, the field, and the societal formation as a whole of all interrelated fields. The social construction of the person can be described in terms of role-allocation, while the fields themselves can be seen as aggregates of related role-sets. We can thereby study the specific effects of an assumedly dominant field by examining formative processes at the levels of both the social person, and societal formations.

This conclusion should be connected to the issue of 'complexity' as stated in the introduction. We are now analytically able, not only to compare societies as being more and less 'complex', but also to compare the processes relating dominant and dominated elements in complex wholes. We can cross-culturally account for dynamic directions over time in social person and societal formations.

It thus seems fruitful to distinguish between 'scale' and 'complexity', and manipulate the scale variable to identify modes of empirical complexity. We can further operationalize the notion of complexity by studying the number of distinct fields and the way they interrelate in societies.

In this way, the question of structural dominance in 'societies' and smaller entities may be formulated in operational terms and be empirically analyzed. As my main point, we can do so by applying some elementary notions from our common anthropological language of social organization and culture.

The above conclusion can be submitted to tests of demonstration and falsification. For example, we can clarify the statements about inter-field dominance by partly or wholly repeating the study focussing our observation upon alternative personnel-sets in Herat such as nomads or urban upper-class people. We can obtain further precision through historical material shedding light upon social (dis-)continuities over time in Herat and comparative exercises in terms of relevant analytical dimensions. Concerning the latter, it would be particularly interesting to include societies in Central Asia and elsewhere in which irrigated agriculture, stratification, and state organization are important components. A point made by Barth during the final phase of the symposium sketches such a comparison:

I was also struck by the similarity and difference between Herat $\ldots$ and my Swat valley in the other end of the Afghan area, which is ecologically similar you know: A nice big valley that is too dry for cultivating unless you have irrigation channels, and you do 20 have them. Why then is political life so staggeringly different in those two places? You can surely approach it by looking at any kinds of integrations that are created by how people in fact 
aggregate their activity in domains: That the feudal kind of patron-client ties that are fundamental to social life in Swat are a major premise for all the other features that distinguish that valley from the Herat valley. Because of this construction of social persons as patrons and chiefs and landowners versus clients and peasants, they will make the kind of society that you have in Swat, or when they do not have it or have alternative concepts of how you construct a person like Herat, they will make a Herat society (Barth, in Blom 1972, session 10, p. 5).

\section{Final remarks: social fields as analytic units}

I have applied to the organization of this material a notion of social fields as the critical analytic units. A field is a relatively bounded interconnexion system stretched out in socio-space. The size of a field is attributed to the magnitude of personnel which it organizes. It is essentially with this meaning of size that I have defined scale, and in the analysis I have varied the levels of scale in order to discover fields and distinguish among them.

The quantitative aspect of numbers, size, and density are relevant, as well as the temporal aspect of durability. Organizational proper dynamics are a further definitional attribute of a social field; by manipulating scale as a variable, I could identify different social dynamics characterizing the various respective circumscribed entities.

One field contains a distinct set of the social prerequisites for individual lives in society, i.e. for the social construction of social persons. And a set of fields can be combined into an account of the society as a whole. I see society as an overall system of the total set of social prerequisites operative in the social formation of the persons studied.

A social field is an aggregate of social relationships which are sets of complementary roles. Social relationships are interconnected in the social person in the sense that a number of roles are combined in the person that is part of the totality of fields making up his society. ${ }^{8}$

In the study of social fields, the discovery process includes the observation of empirical events in which task and issue-oriented relations become activated. The action units themselves must be identified and characterized in terms of their organizational compusition and inventory, then mapped and summarized as aggregate piclures. The critical data concern the generation of organizational palterns through inter-unit relations, the social occasions for their activization, the moves, and tepercussions of moves of actors vis-à- vis each other. Through the simulation of social processes we is entes on We start by describing patterns in emically codified events, and move coward etic accounts of fields as super-individual systems. ${ }^{9}$

The next step concerns the question of dominance in inter-field relations - the problem of 'order of orders' to paraphrase LeviStrauss (1967). Each field is in itself a system of dominating and Strauss (1967). Each field is more complex question concerns the relative dominance of one (or more) of the several fields comprising society.

The order of orders has two aspects: the causative functions of The orfic fields in the formation of social person and in the societal specilic fields in whole. Pursuing this question we can study generatively both the processes of the social construction of social person atively both the processes of the social itself (cf. Barth 1966, 1972). and the social construction of society itself (cc. Barth are interrelated

Considering dominance, I assume that all fields are interrelated and causative of each other, but also that some fields and relationships are more determinative and causative than others, a point demonstrated above. A specific field becomes dominant because the demonstrated above. A specte allocation in general for most people, and roles it in social relationships integrate the population in an especially effective way. Thereby that field's proper dynamics can work with greater force both upon the actor and the society as a work w imply no notions of structural harmony or equilibrium. Kather, I have shown a case where some fields have destructive Kather, I have shown a case where are social processes of destruction of social persons. ${ }^{10}$

The procedure does not arbitrarily presume that large fields are Thesarily more important than small ones, or that specific fields necessarily more important than small ones, or thied to design the are more important than others. Rather, I have tried to designtions. analysis so as to facilitate operationalinvestigation olsical pattern

At the phenolype level, a social field as an empirical pattern of social events, cultural codes, and organizational circumstances sertains to one society. At this level, a given field may be conceppertains to one society. At this level, a gizen thich has litule or no tualized in terms of an empirical syndrome which has little or no comparative value. But the empirical patterns designating ficlds must be analyzed in terms of more elementary determinants or must be analyzed in processes, and at this geneolype level described the proper dynamics oflocality irrigation, region, and econony in Herat as composite or ollocalty, irigation, region, and cconony in aggregate processes, and thereby trying to identify their enter nat ure. As a further step I then resolved these proper dynamic into logically more simple notions easier to use in comparative discussion.

On one hand, then, the idea of fields as aggregates of events 
extended in social space and time is designed to account for the unique and substantive properties of a society as it exists at a given point in history. On the other hand, the integration of formal analytic concepts and statements into the procedure adds to the potential of the field concept as a tool for comparative analysis (cf. Grønhaug, in press).

The social field concept is a version of the general system idea. Events within one part of a field system affect its other parts more directly than sectors outside that field. The field is an interrelated whole with a degree of boundedness distinguishing it from other fic!ds. The notion of field as a relatively bounded entity in rela'ionships of 'export' and 'import' with other fields is an 'open systems' variant of general systems theory (cf. von Bertalanffy 1973).

'Sociely' must then be thought of as system of systems. Social reality is by its nature multi-dimensional, and we must account for as many qualitatively and quantitatively different aspects of societies as possible, while maintaining a consistent language about the commonly 'social'. For this task the multiple field approach may be of some use.

The relevant dimension for describing societies can be conceptualized in terms of proper dynamics. We have noted how a single dimension of proper dynamics manifests itself at several, more and 1 is inclusive organizational levels of scale (cf. section 3.2.2.). However, Herati society cannot validly be imagined as a single hierarchy of organizational levels in only one dimension. We must envisage society as a composite of many hierarchies (of economy, religion, power, etc.), each hierarchy representing specific proper dynamics and displaying specific organizational scale levels.

When considering the scale of society, dichotomies like 'micro: macro', 'small-scale:large-scale', 'community:society', etc. can be misleading. We must understand society as a composite of several hierarchies, each containing multiple levels of scale, and not merely as a two-level entity (cf. Sinha 1972; Schwartz 1972; Grønhaug
1971 a, 1972, in press).11

Finding the scale of a specific society thus appears to be a frustrating problem. Since Herati society is multi-dimensional, and each dimension manifests itsclf at many different levels of scale, how can we then talk of Herati suciety as being of this or that numerical size? It seems that any answer to this begs for further specification.

I think of society in relation to a focial set of actors, and I see their society as that overall system which comprises the tutal set of social prerequisites for their construction as social persons. The overall wiety of niy Herati sharecroppers consists of several fields at different levels of scale. It would be erroneous to select one of the fields with its specific scale and label it 'Herati society', since all fields in Herat are operative in the formation of the sharecroppers and their social partners.

The best we can do is to talk of the size of fields as specified organizational dimensions. Later we can try to identify the most dominant of the fields and point to the effects and functions of that field in the construction of persons and society. From this point of reference we can then consider the scale of the dominant field as a critical organizational level in a society. But this dimension is not identical with the scale of that overall society, something which cannot be expressed in simple numerical terms. The following remark clarifies this:

Demographic scale is what we mostly talk about when we are thinking of scale, sheer numbers of people within any countable segregate, and the only question is what can be counted? We find we can count almost anything better than we can (count) societies (Schwartz in Blom 1972, session 10, p. 11).

In Herat $I$ have pointed to the regional economy as the critical level of organization; it includes a population of about one million. Integration within the regional economy has its own dynamics with determinative effects upon smaller sub-systems operative in social person formation in Herat. People there are also part of larger fields: the Afghan state, Islam, the world-wide economicpolitical system. The analytic task is then to locate and evaluate the significance of the impacts of such larger fields, and study the processes of change whereby specific macro-fields become more or less determinative in the lives of people in Herat.

Thus, the significant question for understanding a society as a whole concerns the processes whereby a set of actors is, or is becoming, part of a social field that has, or is acquiring, decisive determinative effects upon all the fields that include those actors. We can tackle this problem by analytically resolving the notion of 'society' into elementary components of fields. We can identify the scale of fields. But without demonstrating a specific field's determinative signilicance for the overall society, it is meaningless - or at best bewildering - to regard the scale of a field as the scale of the society in question.

Scale as simply numerical size is an interesting variable, since we can use it to identify different significant fields, especially to find the extension and functional mode of the determinative field (s) in a suciety. Thereby, we can more clearly understand the dynannics of the social construction of society itself. 